\title{
Fabrication and in vitro characterization of polymeric nanoparticles for Parkinson's therapy: a novel approach
}

\author{
Neha Gulati ${ }^{1, *}$, Upendra Nagaich ${ }^{2}$, Shubhini Saraf ${ }^{3}$ \\ ${ }^{1}$ Department of Pharmaceutics, School of Pharmacy, Bharat Institute of Technology, Meerut, India, ${ }^{2}$ Amity institute of \\ Pharmacy, Amity University, Noida, India, ${ }^{3}$ School of Biosciences and Biotechnology, Babasaheb Bhimrao Ambedkar \\ University, Lucknow, India
}

\begin{abstract}
The objective of the research was to formulate and evaluate selegiline hydrochloride loaded chitosan nanoparticles for the Parkinson's therapy in order to improve its therapeutic effect and reducing dosing frequency. Taguchi method of design of experiments (L9 orthogonal array) was used to get optimized formulation. The selegiline hydrochloride loaded chitosan nanoparticles (SHPs) were prepared by ionic gelation of chitosan with tripolyphosphate anions (TPP) and tween 80 as surfactant. The SHPs had a mean size of $(303.39 \pm 2.01) \mathrm{nm}$, a zeta potential of $+32.50 \mathrm{mV}$, and entrapment efficiency of SHPs was $86.200 \pm 1.38 \%$. The in vitro drug release of SHPs was evaluated in phosphate buffer saline $(\mathrm{pH} 5.5)$ using goat nasal mucosa and found to be $82.529 \% \pm 1.308$ up to $28 \mathrm{~h}$. Release kinetics studies showed that the release of drug from nanoparticles was anomalous (non-fickian) diffusion indicating the drug release is controlled by more than one process i.e. superposition of both phenomenon, the diffusion controlled as well as swelling controlled release. SHPs showed good stability results as found during stability studies at different temperatures as mentioned in ICH guidelines. The results revealed that selegiline hydrochloride loaded chitosan nanoparticles are most suitable mode of delivery of drug for promising therapeutic action.
\end{abstract}

Uniterms: Chitosan/nanoparticles/evaluation. Chitosan/nanoparticles/formulation. Selegiline hydrochloride/nanoparticles/drug release. Parkinson's therapy. Polymeric nanoparticles/formulation. Polymeric nanoparticles/evaluation. Taguchi Design.

O objetivo da pesquisa foi formular e avaliar nanopartículas de quitosana contendo cloridrato de selegilina para terapia do Parkinson, a fim de melhorar o seu efeito terapêutico e reduzir a frequência de dosagem. Método de Taguchi, de planejamento experimental, (L9 matriz ortogonal) foi usado para obter a formulação otimizada. As nanopartículas de quitosana contendo cloridrato de selegilina (PCHs) foram preparadas por gelificação iônica de quitosana com ânions tripolifosfato (TPP) e Tween 80 como tensoativo. As PCHs apresentaram tamanho médio de $(303.39 \pm 2,01) \mathrm{nm}$, potencial zeta de +32.50 mV e eficiência de encapsulação de $86.200 \pm 1,38 \%$. A liberação do fármaco in vitro foi avaliada em solução salina de tampão fosfato ( $\mathrm{pH} 5,5)$, usando a mucosa nasal de cabra e o resultado encontrado foi de $82.529 \% \pm 1.308$, acima de $28 \mathrm{~h}$. Estudos de cinética de liberação mostraram que a liberação do fármaco das nanopartículas foi por difusão anômala (não fickiana), indicando que é controlada por mais de um processo, ou seja, a superposição dos fenômenos de difusão controlada e intumescimento. As PCHs mostraram resultados de boa estabilidade, encontrada durante os estudos de estabilidade em temperaturas diferentes, como mencionado em diretrizes do ICH. Os resultados revelaram que o sistema de nanopartículas de quitosana contendo cloridrato de selegilina é o mais adequado sistema de liberação de fármacos de ação terapêutica promissora.

Unitermos: Quitosana/nanopartículas/avaliação. Cloridrato de selegilina/nanopartículas/sistema de liberação. Doença de Parkinson/terapia. Nanopartículas poliméricas/formulação. Nanopartículas poliméricas/avaliação. Planejamento de Taguchi.

\footnotetext{
*Correspondence: Neha Gulati. Department of Pharmaceutics, School of Pharmacy, Bharat Institute of Technology, 250103 - Meerut - Uttar Pradesh, India. E-mail: ngulati88@gmail.com
} 


\section{INTRODUCTION}

Parkinson's disease, also known as Paralysis Agitans, is an idiopathic neurodegenerative disorder of central nervous system. It is a consequence of death of dopamine containing cells in substantia nigra, a region in midbrain (Jankovisc, 2008) Monoamine oxidase (MAO), an intracellular enzyme, degrades dopamine which diminishes the net amount of dopamine available. To prevent the degradation of dopamine, MAO inhibitors are prescribed. Selegiline hydrochloride is best known as an irreversible inhibitor of MAO. It is a levorotatory acetylenic derivative of phenethylamine (Davie, 2008). It inhibits MAO by acting as a 'suicide' substrate for the enzyme. It is converted by MAO to an active moiety which combines irreversibly with the active site and/or the enzyme's essential FAD cofactor. Because selegiline has greater affinity for type $B$ rather than for type A active sites, it can serve as a selective inhibitor of MAO type B if it is administered at the recommended doses (Pae et al., 2007). Selegiline hydrochloride has high protein binding (up to $99 \%$ ), thus one best approach to overcome this problem is to give intranasally which target drug directly to brain via absorption through olfactory mucosa (Sharma, Khatri, Patil, 2010). For this purpose, nanoparticles made up of mucoadhesive and biocompatible polymers serve the best. Chitosan nanoparticles are submicron colloidal drug carrier systems which are biodegradable, non-toxic and non-immunogenic (Wilson et al., 2008). Chitosan nanoparticles have various advantages like: site specific targeting, prevention of dose dumping via its sustained and controlled release nature and its mucoadhesive nature (Kockisch et al. 2003). These attributes indirectly help in reducing dose and frequency of administration which improves patient compliance (Sailaja, Amareshwar, Chakravarty, 2010).

In the present work, we attempted to develop sustained release mucoadhesive selegilline hydrochloride loaded chitosan nanoparticles which can serve as intranasal drug delivery systems. The formulation was characterized using scanning electron microscopy (SEM), zeta potential, polydispersity index and entrapment efficiency. Permeation of drug from formulation through excised goat nasal mucosa was examined by an in vitro method.

\section{MATERIAL AND METHODS}

\section{Material}

Selegiline hydrochloride was received as gift sample from Neha Pharma Pvt. Ltd., Mumbai, India. Chitosan ( $85 \%$ deacetylated) was purchased from Sigma Aldrich Pvt. Ltd., Mumbai, India. Sodium Tripolyphosphate and Tween 80 were purchased from Loba Chemie Pvt. Ltd. (Mumbai, India) and S.D Fine-Chem Pvt. Ltd. (Mumbai, India), respectively. All other reagents were of analytical grade and used as purchased.

\section{Statistical experimental design for formulation optimization}

The Taguchi method of design of experiments is a statistical tool, which mainly relies upon the systematic approach of conducting minimum number of experiments with the use of a mathematical instrument known as orthogonal arrays (OA) (Varshosaz et al., 2008). The method is primarily utilized to envisage the contribution of each variables and their level to attain optimum combination. The method also gives full description of all the factors that affect the performance parameters. Based on the number of factors and their levels, $\mathrm{L}_{9}$ $\left(3^{4}\right)$ orthogonal array was employed (Senthilkumar, Vaidyanathan, Sivaraman, 2010). It includes four factors (formulation variables) i.e. polymer concentration $(\% \mathrm{w} / \mathrm{v})$, cross-linking agent concentration $(\% \mathrm{w} / \mathrm{v})$, surfactant concentration $(\% \mathrm{v} / \mathrm{v})$ and stirring speed $(\mathrm{rpm})$ were selected. All the factors were assigned three levels i.e. low, medium and high as shown in Table I. L9 orthogonal array is explained in Table II, which describes number of formulations to be developed for optimization. Apart from designing a formulation table, optimizations are done on the basis of two main approaches and signal to noise ratio ( $\mathrm{S} / \mathrm{N}$ ratio). $\mathrm{S} / \mathrm{N}$ ratio takes into account the mean and variation between results (Dobrazanski, Domagala, Silva, 2007). The two approaches are smaller-the-better and larger-the-better. Smaller-the-better is usually the chosen $\mathrm{S} / \mathrm{N}$ ratio for all undesirable characteristics like "defects", for which the ideal value is zero. Examples are size of nanoparticles, polydispersity index while largerthe-better is taken when ideal value is larger. Examples are drug entrapment efficiency, and drug loading, among others (Jahanshahi, Najafpour, Rahimnejad, 2008).

\section{Preparation of selegiline hydrochloride loaded chitosan nanoparticles}

Chitosan nanoparticles containing the drug selegiline hydrochloride were prepared by ionotropic gelation technique (Calvo et al., 1997). Accurately weighed chitosan was dissolved in $1 \% \mathrm{v} / \mathrm{v}$ acetic acid solution, to which tween 80 and drug was added. Sodium 
TABLE I - Experimental control factors and their levels for chitosan nanoparticles formulation

\begin{tabular}{lcccc}
\hline \multirow{2}{*}{ S.No. } & Variables & Low (1) & Medium (2) & High(3) \\
\cline { 3 - 4 } & & $1: 0.1 \%$ & $1: 0.2 \%$ & $1: 1.5 \%$ \\
2. & Polymer Concentration & $0.25 \%$ & $0.50 \%$ & $0.75 \%$ \\
3. & Concentration of Tween 80 & $0.1 \%$ & $0.25 \%$ & $0.5 \%$ \\
4. & Concentration of TPP & 1000 & 1500 & 2000 \\
\hline
\end{tabular}

TABLE II - Taguchi $\mathrm{L}_{9}\left(3^{4}\right)$ orthogonal array for chitosan nanoparticles formulation

\begin{tabular}{lllll}
\hline \multirow{2}{*}{ Batches } & \multicolumn{4}{c}{ Parameters } \\
\cline { 2 - 5 } & A & B & C & D \\
\hline SHP1 & 1 & 1 & 1 & 1 \\
SHP2 & 1 & 2 & 2 & 2 \\
SHP3 & 1 & 3 & 3 & 3 \\
SHP4 & 2 & 1 & 2 & 3 \\
SHP5 & 2 & 2 & 3 & 1 \\
SHP6 & 2 & 3 & 1 & 2 \\
SHP7 & 3 & 1 & 3 & 2 \\
SHP8 & 3 & 2 & 1 & 3 \\
SHP9 & 3 & 3 & 2 & 1 \\
\hline
\end{tabular}

tripolyphosphate (TPP) was dissolved in distilled water. To the chitosan-drug solution, TPP solution was added dropwise through a no. 4 syringe needle and continuously stirred using mechanical stirrer (Remi Motors-RO-123, RPM 4000) at room temperature for $30 \mathrm{~min}$, which leads to the formation of nanoparticles. Subsequently $\mathrm{pH}$ was adjusted to 5.5 with the help of certain amount of $1 \mathrm{~N}$ $\mathrm{HCl}$ or $\mathrm{NaOH}$ and then centrifuged at $12000 \mathrm{rpm}$, using refrigerated centrifuge (SIGMA 3-18K, Sartorius) (Wang, Chi, Tang, 2008).

\section{HPLC analytical method}

The HPLC system for selegiline hydrochloride included a VP Shimadzu Liquid Chromatograph LC-10AT pump and a SPD-10A ultraviolet (UV)/visible detector. A 25-cm-long, 4-mm inner diameter stainless-steel RP-18 column (Merck, Darmstadt, Germany) was used. The mobile phase was acetonitrile: $\mathrm{pH} 7.0$ buffer (65:35) at a flow rate of $1.0 \mathrm{~mL} / \mathrm{min}$. The UV/visible detector was set to $205 \mathrm{~nm}$ (Chena et al., 2011). The retention time of selegiline hydrochloride was $7.75 \mathrm{~min}$ (Chena et al., 2011). The representative HPLC chromatogram is shown in Figure 1.

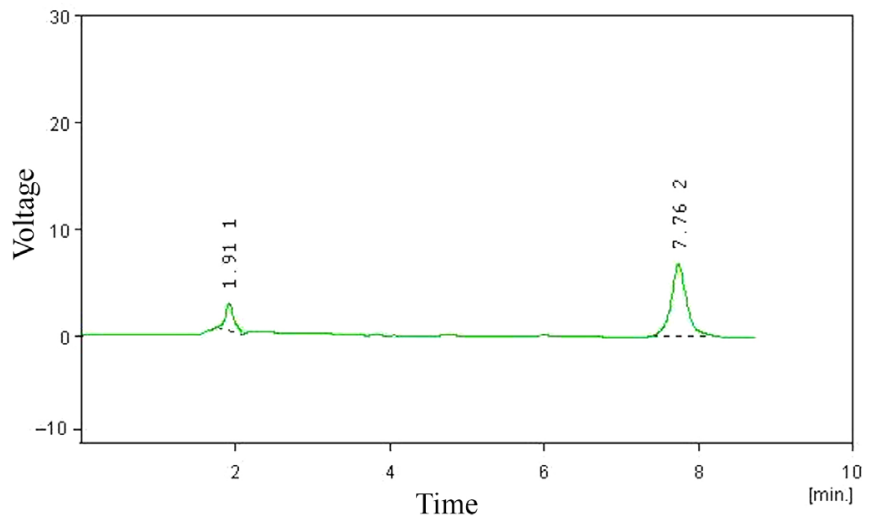

FIGURE 1 - Representative Chromatogram of selegiline hydrochloride (Peak at $7.762 \mathrm{~min}$ ).

\section{Characterization of Chitosan nanoparticles}

\section{Shape and surface morphology}

Shape and surface morphology of chitosan nanoparticles was visualized by scanning electron microscopy (LEO-430 Cambridge and U.K). Samples were prepared by lightly sprinkling nanoparticles on a double adhesive tape, on an aluminum stub. The stubs were then coated with gold to a thickness of 200 to $500 \mathrm{~A}^{0}$ under an argon atmosphere using gold sputter module in a high vacuum evaporator. The samples were then randomly scanned and photomicrographs taken at different magnifications with SEM (Paharia et al., 2007).

\section{Particle size and zeta potential measurement}

Particle size was measured with the help of photon correlation microscopy. For the determination of particle size, samples were prepared by tenfold dilution of $1 \mathrm{ml}$ of nanoparticulate suspension with distilled water. The analysis was carried out in triplicate. Average particle size and polydispersity index were measured by photon correlation spectroscopy at $90^{\circ}$ angle at $25^{\circ} \mathrm{C}$. Zeta potential was determined by the electrophoretic mobility of chitosan nanoparticles in $\mathrm{U}$ type tube at $25^{\circ} \mathrm{C}$, using a Zetasizer (3000HS Malvern Instruments, UK) (Alhaj et al., 2008). 


\section{Drug entrapment efficiency}

The entrapment efficiency of the formulation was determined upon the centrifugation of fixed quantity of aqueous nanoparticulate suspension (about $10 \mathrm{~mL}$ ) at $12000 \mathrm{rpm}$ for 30 minutes at $20{ }^{\circ} \mathrm{C}$ (SIGMA 3-18K, Sartorious). The absorbance of unencapsulated drug was evaluated in the supernatant via HPLC system using calibration curve with plain chitosan nanoparticles (SHPs) as blank which had also been prepared and treated similar to the drug loaded nanoparticles (Joseph, Sharma, 2007). The analysis was carried out in triplicate and mean taken. The drug entrapment of chitosan nanoparticles was calculated by the following equation.

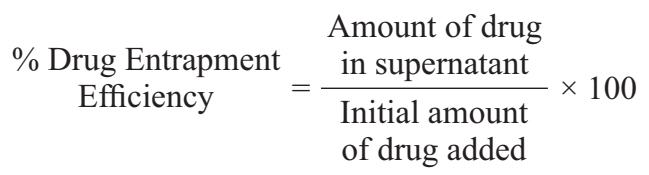

\section{In vitro permeation studies}

In vitro permeation study was conducted using Keshary-Chien (K-C) cell with an effective diffusion area of $2.0 \mathrm{~cm}^{2}$ and a cell volume of $25 \mathrm{~mL}$. The diffusion cells were thermoregulated with a water jacket at $37 \pm 2{ }^{\circ} \mathrm{C}$. Excised goat nasal mucosa was used for the evaluation of formulation permeation which was obtained from local slaughter house within 15 minutes of goat sacrifice. After skin removal, the nose was stored on ice cold phosphate buffer ( $\mathrm{pH}$ 5.5) and nasal mucosa was carefully removed using forceps and surgical scissors. The mucosal tissues were immediately immersed in Ringer's solution. The freshly excised nasal mucosa was mounted on the diffusion cell and $10 \mathrm{~mL}$ of aqueous drug loaded nanoparticulate suspension (containing drug equivalent to $10 \mathrm{mg}$ ) was kept on it. The receptor chamber was filled with fresh saline (phosphate buffer $\mathrm{pH}$ 5.5). $1 \mathrm{ml}$ of sample aliquots were withdrawn at predetermined time intervals and subsequently replenished with an equal amount of phosphate buffer. The samples were filtered and diluted appropriately. The samples were analyzed using HPLC system (Basu, Chakrabatorty, Bandyopadhyay, 2009; Basu, Bandyopadhyay, 2010).

\section{Release kinetics studies}

The release kinetics of drug was studied by plotting the results of the in vitro drug release study with various kinetic models like zero order (cumulative percent drug release $v s$ time), first order (log cumulative percent drug release $v s$ time), Higuchi's kinetics (cumulative percent drug release $v s \sqrt{ }$ time), and Korsmeyer and Peppas equation (log cumulative percentage of drug release vs log time) (Bourne et al., 2002; Korsmeyer et al., 1983).

\section{Stability studies}

A study was also carried out to assess the stability of Selegiline hydrochloride loaded chitosan nanoparticles (SHP4). For this purpose, samples were kept in borosilicate glass vials and stored at room temperature, refrigerator $\left(5 \pm 1{ }^{\circ} \mathrm{C}\right)$ and $45 \pm 1{ }^{\circ} \mathrm{C}(75 \%$ relative humidity) in the stability chamber. Samples were analyzed at the intervals of $0,7,14,21,28,35$ and 45 days for their drug content as well as any changes in physical appearance (Zhang et al., 1996).

\section{RESULTS AND DISCUSSION}

Chitosan nanoparticles can be prepared by several techniques reported in literature like microemulsion method, ionotropic gelation method and solvent emulsification diffusion method. Ionotropic gelation method being mild with simple laboratory set-up was used in the present study. Remarkably high percent drug entrapment $(86.200 \pm 1.38 \%)$ and small particle size $(303.39 \pm 2.01 \mathrm{~nm})$ was observed with this method. In this method, polymer (chitosan), crosslinking agent (sodium tripolyphosphate) and surfactant (tween 80) were selected. $\mathrm{pH}$ of the formulation was considered as important factor as it determines the degree of cross-linking and also the $\mathrm{pH}$ of delivery site. Crosslinking of polymer is higher at acidic $\mathrm{pH}$ as reported. They concluded that at $\mathrm{pH} 3$, only phosphoric ions are present which cause ionic cross-linking while at $\mathrm{pH} 9$, cross-linking via deprotonation is achieved (Bhumkar, Pokharkar, 2009).

Taguchi design enabled selection of optimized formulation. Four factors (viz. drug to polymer ratio, concentration of surfactant, concentration of cross-linking agent and stirring speed) were selected, as these are most important factors (independent variables), which can affect particle size, entrapment efficiency and in vitro drug release (dependent variables). The range for drug to polymer ratio was taken from 1:0.1 to $1: 1.5 \mathrm{w} / \mathrm{w}$. In comparison with other concentrations, $1: 0.1 \mathrm{w} / \mathrm{w}$ showed highest entrapment $(41.46 \% \pm 0.65)$ with minimum particle size $(415 \mathrm{~nm} \pm 0.23)$. Different concentrations of cross-linking agent were also taken from 0.10 to $0.5 \%$, out of which $0.25 \%$ was found as optimum on the basis of smallest particle size $(506 \mathrm{~nm} \pm 0.76)$ and high entrapment $(56.23 \% \pm 0.43)$. Concentration of surfactant i.e. $0.5 \% \mathrm{v} / \mathrm{v}$ tween 80 was selected on the basis of smallest particle size $(415 \mathrm{~nm} \pm 0.23)$ as well as the fact that no aggregation was 
observed up to 24 hours. Stirring speed of $1500 \mathrm{rpm}$ was selected as optimum with respect to particle size $(415 \mathrm{~nm}$ $\pm 0.45)$ and entrapment efficiency $(52.84 \% \pm 0.38)$.

On the basis of evaluation parameters, optimized formulation should have medium level of drug to polymer ratio $(1: 0.2 \% \mathrm{w} / \mathrm{v})$, low level of surfactant $(0.25 \% \mathrm{v} / \mathrm{v})$, medium level of cross-linking agent $(0.25 \% \mathrm{w} / \mathrm{v})$ and high level of stirring speed (3000 rpm), as per the three levels of factors taken for experimental design.

The particle size and zeta potential of chitosan nanoparticles was analyzed by PCS and zetasizer. Nanoparticles were round in shape with a smooth appearance as shown in Figure 2. The values for the average particle size, zeta potential and polydispersity index are tabulated in Table III. Optimized formulation showed an average particle size and polydispersity index of $303.39 \pm 2.01$ and $0.313 \pm 0.28$, respectively. The zeta potential was found to be $+28.5 \mathrm{mV}$.

On the basis of Taguchi design, smaller-the-better of $\mathrm{S} / \mathrm{N}$ ratio was considered for the particle size and polydispersity index. SHP4 showed minimum average particle size and polydispersity index of $303.39 \pm 2.01$ and $0.313 \pm 0.28$, respectively, which can be taken into account as optimized in terms of particle size and polydispersity index. Shape and surface morphology of the selegiline hydrochloride loaded chitosan nanoparticles were visualized by scanning electron microscopy (SEM). They were found to be spherical and with a smooth appearance as shown in Figure 2. Chitosan nanoparticles displayed uniform size distribution. This may be attributed to the optimum combination of drug to polymer ratio and stirring speed. Polymer concentration ( $0.2 \%$-medium level) was not so viscous, thus high stirring speed (3000 rpm) could easily breakdown the formed nanoparticles. As reported in literature, higher concentration of polymer, results in viscous solution which may resists the particle breakdown by stirring and lead to increase in particle size (Thagele, Mishra, Pathak, 2011). Smaller size helps in targeting and increased penetration of drug through biological membranes (Vasir, Reddy, Labhasetwar, 2005).

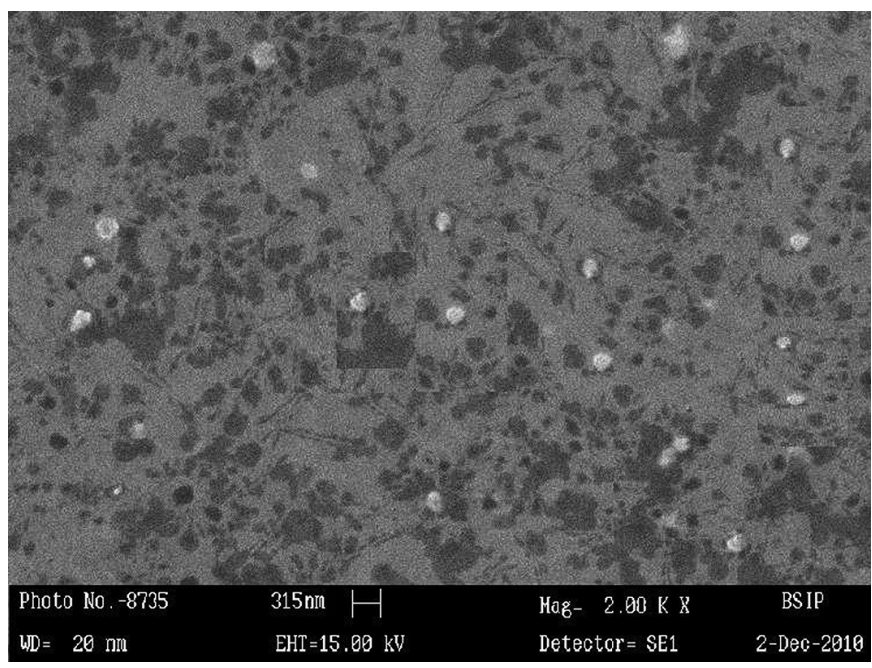

FIGURE 2 - SEM Photomicrograph of selegiline hydrochloride loaded Chitosan nanoparticles.

The measurement of the zeta potential allows predictions of storage stability of colloidal dispersion. In general, particle aggregation is less likely to occur for charged particles (high zeta potential) due to electric repulsion (Hans, Lowman, 2002). The mean zeta potential was found to be $+32.50 \pm 1.93 \mathrm{mV}$, which may be attributed to the positive charges on polymer matrices and surfactant's mixture. Tween 80 also provides steric stability to nanoparticles (Lim, Kim, 2002).

TABLE III - Data for evaluation parameters of selegiline hydrochloride loaded nanoparticles

\begin{tabular}{lcccc}
\hline Formulations & $\begin{array}{c}\text { Average particle } \\
\text { size } \pm \text { S.D }\end{array}$ & Zeta Potential \pm S.D & $\begin{array}{c}\text { Polydispersity } \\
\text { Index } \pm \text { S.D }\end{array}$ & $\begin{array}{c}\text { Entrapment } \\
\text { Efficiency } \pm \text { S.D }\end{array}$ \\
\hline SHP1 & $546.54 \pm 1.85$ & $33.50 \pm 0.83$ & $0.519 \pm 1.93$ & $85.950 \pm 1.20$ \\
SHP2 & $517.53 \pm 0.83$ & $21.71 \pm 0.28$ & $0.554 \pm 2.34$ & $84.070 \pm 2.40$ \\
SHP3 & $437.28 \pm 1.02$ & $22.98 \pm 0.64$ & $0.472 \pm 1.30$ & $78.500 \pm 1.92$ \\
SHP4 & $303.39 \pm 2.01$ & $32.50 \pm 1.93$ & $0.313 \pm 0.28$ & $86.200 \pm 1.38$ \\
SHP5 & $349.48 \pm 0.74$ & $26.50 \pm 2.91$ & $0.314 \pm 0.74$ & $84.660 \pm 0.28$ \\
SHP6 & $624.86 \pm 1.73$ & $27.10 \pm 0.74$ & $0.593 \pm 1.08$ & $83.349 \pm 1.93$ \\
SHP7 & $658.48 \pm 1.20$ & $26.80 \pm 0.76$ & $0.602 \pm 1.29$ & $83.801 \pm 1.06$ \\
SHP8 & $574.89 \pm 0.29$ & $35.40 \pm 1.83$ & $0.652 \pm 1.38$ & $81.000 \pm 0.48$ \\
SHP9 & $536.78 \pm 1.32$ & $36.83 \pm 1.94$ & $0.507 \pm 2.18$ & $82.670 \pm 0.93$ \\
\hline
\end{tabular}

(Values are mean \pm standard deviation) 
Entrapment efficiency of selegiline hydrochloride loaded chitosan nanoparticles was analyzed and data is shown in Table III. According to Taguchi design, largerthe-better of $\mathrm{S} / \mathrm{N}$ ratio is considered as optimum. SHP4 showed average drug entrapment efficiency of $86.200 \%$ \pm 1.38 , which is higher amongst other formulations. Percent drug entrapment was found to be high i.e. $86.200 \pm 1.38$ in formulation SHP4, as compared to other formulations. Effective entrapment is totally based on nature of polymer and solubility of drug in it. Since chitosan is a hydrophilic polymer and selegiline hydrochloride is also freely soluble in water. Thus, more drugs could be entrapped into the polymer matrices. Apart from the nature of drug and polymer, concentration of polymer (medium level) was enough to entrap more amount of drug, which leads to increase in entrapment (Thagele, Mishra, Pathak, 2011). If the concentration of polymer is further increased, a decrease in entrapment is observed, which may be due to higher viscosity of the polymeric solution which hinders diffusion of drug in the polymer. Inspite of optimum concentration of chitosan, concentration of cross-linking agent played a major role in high entrapment. Higher concentration of crosslinking agent could gelate more amount of polymer, thereby increasing the amount of drug entrapped into the nanoparticles (Deng, Zhou, Luo, 2006).

In vitro drug release was carried out using K-C (diffusion) cell. Figure 3 showed release profile of selegiline hydrochloride from chitosan nanoparticles. The release of drug from the drug-loaded formulations varied from $58.182 \pm 1.135$ to $82.529 \pm 1.308$ for 28 hours, depending on the drug-to-polymer ratio. The in vitro release profile of drug loaded chitosan nanoparticles revealed that the optimized batch showed an initial burst release up to $4.384 \% \pm 1.92$, which may be due to presence of adsorbed drug on the surface of polymer, which was followed by sustained release of $76.74 \pm 1.308$ up to 28 hours because the drug slowly get diffused to the surface through the polymer core. This release pattern may contribute in presenting the drug immediately after instilling in the nasal cavity and sustained release up to 24 hours would contribute to lower dosing frequency. The slow release of the selegiline hydrochloride from all formulations suggests homogeneous entrapment of the drug throughout the systems.

It was found that the in vitro drug release of SHP4 was best explained by zero order, as the plots showed the highest linearity $\left(\mathrm{R}^{2}=0.979\right)$, followed by Higuchi's equation $\left(\mathrm{R}^{2}=0.889\right)$ and first order $\left(\mathrm{R}^{2}=0.787\right)$. The corresponding plot (log \% cumulative drug release $v s$ log time) for the Korsmeyer-Peppas equation indicated good linearity $\left(\mathrm{R}^{2}=0.969\right)$. The release exponent ' $\mathrm{n}$ ' was found to be 1.002. On fitting the in vitro release data into different equations, optimized formulation showed zero order release as it has high linearity, followed by Higuchi's equation and first order as shown in Table IV. The value of release component ' $n$ ' obtained via Korsmeyer-Peppas equation is 0.969 which appears to indicate the anomalous (non-fickian) diffusion indicating that the drug release is controlled by more than one process i.e. superposition of both phenomenon, the diffusion controlled and swelling controlled release (Deng, Zhou, Luo, 2006).

The results of drug content of optimized formulation SHP 4 after 45 days of stability testing at different storage conditions were shown in Table V. The results of stability studies clearly demonstrate that the formulation is more stable when stored at $4{ }^{\circ} \mathrm{C}$ and room temperature than at $45 \pm 2{ }^{\circ} \mathrm{C} / 75 \% \mathrm{RH}$. This may be due to nanoparticulate degradation at higher RH and temperature (Nesalin, Smith, 2012).

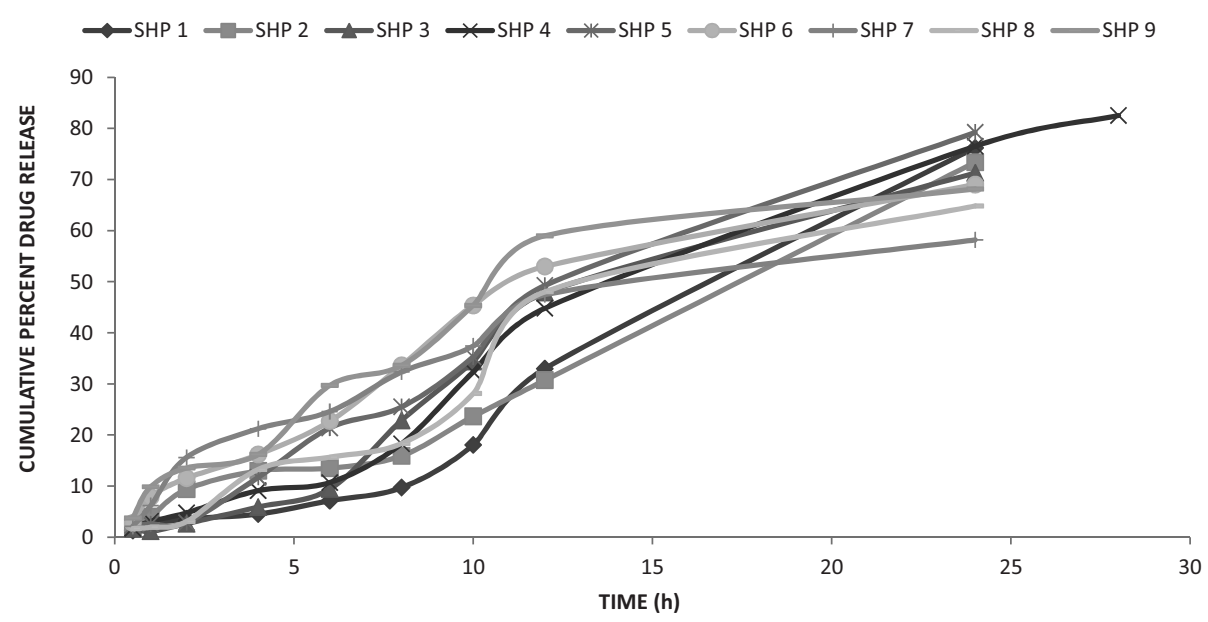

FIGURE 3 - In vitro drug release profiles of selegiline hydrochloride loaded chitosan nanoparticles. 
TABLE IV - Release parameters of chitosan nanoparticles (SHP4)

\begin{tabular}{lcccccccc}
\hline Formulation & \multicolumn{2}{c}{ Zero order } & \multicolumn{2}{c}{ First order } & \multicolumn{2}{c}{ Higuchi } & \multicolumn{2}{c}{ Korsmeyer-peppas } \\
\hline \multirow{2}{*}{ SHP4 } & $\mathbf{K}$ & $\mathbf{R}^{2}$ & $\mathbf{K}$ & $\mathbf{R}^{2}$ & $\mathbf{K}$ & $\mathbf{R}^{2}$ & $\mathbf{N}$ & $\mathbf{R}^{\mathbf{2}}$ \\
\cline { 2 - 9 } & 3.129 & 0.979 & 0.061 & 0.787 & 16.82 & 0.889 & 1.002 & 0.969 \\
\hline
\end{tabular}

TABLE V - Stability studies of optimized formulation SHP4

\begin{tabular}{|c|c|c|c|c|}
\hline \multirow{2}{*}{ S. No. } & \multirow{2}{*}{$\begin{array}{c}\text { Sampling Interval } \\
\text { (days) }\end{array}$} & \multicolumn{3}{|c|}{ Drug Content (\%) } \\
\hline & & $5 \pm 1^{\circ} \mathrm{C}$ & Room temperature & $45 \pm 2{ }^{\circ} \mathrm{C} / 75 \% \mathrm{RH}$ \\
\hline 1. & $0^{\text {th }}$ & 100 & 100 & 100 \\
\hline 2. & $7^{\text {th }}$ & $99.53 \pm 0.21$ & $99.47 \pm 0.22$ & $92.56 \pm 0.45$ \\
\hline 3. & $14^{\text {th }}$ & $99.28 \pm 0.07$ & $98.83 \pm 0.13$ & $85.93 \pm 0.36$ \\
\hline 4. & $21^{\text {th }}$ & $99.93 \pm 0.84$ & $98.27 \pm 0.08$ & $76.83 \pm 0.39$ \\
\hline 5. & $28^{\text {th }}$ & $99.75 \pm 0.12$ & $97.88 \pm 0.17$ & $70.97 \pm 0.29$ \\
\hline 6. & $35^{\text {th }}$ & $98.43 \pm 0.12$ & $97.03 \pm 0.12$ & $63.86 \pm 0.13$ \\
\hline 7. & $45^{\text {th }}$ & $98.18 \pm 0.03$ & $96.58 \pm 0.34$ & $57.03 \pm 0.84$ \\
\hline
\end{tabular}

(Values are mean \pm standard deviation)

\section{CONCLUSION}

Selegiline Hydrochloride loaded chitosan nanoparticles were successfully formulated via ionotropic gelation technique using Taguchi design for optimization. The obtained nanoparticles would easily penetrate nasal mucosa by virtue of particle size. Formulation displayed sustained release up to 24 hours that may help to cut down multiple dosing to once-a-day. Therefore, it could be a potential drug delivery system for the targeted therapy of disease.

\section{ACKNOWLEDGEMENTS}

The Authors want to thank Neha Pharma Pvt Ltd. for providing the gift sample of drug. We are also thankful to Babu Banarasi Das National Institute of Technology and Management, Lucknow, U.P., India for providing necessary research facilities.

\section{CONFLICT OF INTEREST}

Authors declare no conflict of interest.

\section{REFERENCES}

ALHAJ, N.A.; ABDULLAH, R.; IBRAHIM, S.; BUSTAMAN, A. Tamoxifen drug loading solid lipid nanoparticles prepared by hot high pressure homogenization techniques. Am. J. Pharmacol. Toxicol., v.3, p.219-224, 2008.
BASU, S.; CHAKRABATORTY, S.; BANDYOPADHYAY, A.K. Development and evaluation of a mucoadhesive nasal gel of midazolam prepared with Linum usitatissimum $L$. seed mucilage. Sci. Pharm., v.77, p.899-910, 2009.

BASU, S.; BANDYOPADHYAY, A.K. Development and characterization of mucoadhesive in situ nasal gel of midazolam prepared with Ficus carica mucilage. AAPS PharmSciTech, v.11, p.1223-31, 2010.

BHUMKAR, D.R.; POKHARKAR, V.B. Studies on effect of pH on cross-linking of chitosan with sodium tripolyphosphate: a technical note. AAPS PharmSciTech, v.7, p.E1-E6, 2009.

BOURNE, D.W.A. Pharmacokinetics. In: BANKER, G.S.; RHODES, C.T. (Eds.). Modern pharmaceutics. New York: Marcel Dekker, 2002. p.67-92.

CALVO, P.; REMUNAN-LOPEZ, C.; VILA-JATO, J.L.; ALONSO, M.J. Novel hydrophilic chitosan polyethylene oxide nanoparticles as protein carriers. J. Appl. Polym. Sci., v.63, p.125-32, 1997.

CHENA, C.C.; FANG, C.L.; AL-SUWAYEHC, S.A.; LEUD, Y.L.; FANG, J.Y. Transdermal delivery of selegiline from alginate-Pluronic composite thermogels. Int. J. Pharm., v.415, p.119-128, 2011.

DAVIE, C.A. A review of Parkinson's disease. Br. Med. Bull., v.86, p.109-127, 2008. 
DENG, Q.Y.; ZHOU, C.R.; LUO, B.H. Preparation and characterization of chitosan nanoparticles containing lysozyme. Pharm. Biol., v.44, p.336-42, 2006.

DOBRAZANSKI, L.A.; DOMAGALA, J.; SILVA, J.F. Application of taguchi method in the optimization of filament winding of thermoplastic composites. Arch. Mat. Sci. Eng., v.28, n.3, p.133-40, 2007.

HANS, M.L.; LOWMAN, A.M. Biodegradable nanoparticles for drug delivery and targeting. Curr. Opin. Solid. State Mater. Sci., v.6, p.319-27, 2002.

JAHANSHAHI, M.; NAJAFPOUR, G.; RAHIMNEJAD, M. Applying the taguchi method for optimized fabrication of bovine serum albumin (BSA) nanoparticles as drug delivery vehicles. Afr. J. Biotechnol., v.7, p.362-367, 2008.

JANKOVISC, J. Parkinson's disease: clinical features and diagnosis. J. Neurol. Neurosurg. Psychiatr., v.79, n.4, p.368-376, 2008.

JOSEPH, N.M.; SHARMA, P.K. Cross-linked nanoparticles of cytarabine: encapsulation, storage and in-vitro release. Afr. J. Pharm. Pharmacol., v.1, p.10-13, 2007.

KOCKISCH, S.; REES, G.D.; YOUNG, S.A.; TSIBOUKLIS, J.; SMART, J.D. Polymeric microspheres for drug delivery to oral cavity: an in vitro evaluation of mucoadhesive potential. J. Pharm. Sci., v.92, p.1614-1623, 2003.

KORSMEYER, R.W.; GURNY, R.; DOELKER, E.; BURI, P.; PAPPAS, N.A. Mechanism of solute release from porous hydrophilic polymers. Int. J. Pharm., v.15, p.25-35, 1983.

LIM, S.J.; KIM, C.K. Formulation parameters determining the physicochemical characterstics of solid lipid nanoparticles loaded with all-trans retinoic acid. Int. J. Pharm., v.243, p.135-46, 2002.

NESALIN, J.A.J.; SMITH, A.A. Preparation and evaluation of chitosan nanoparticles containing zidovudine. Asian J. Pharm. Sci., v.7, p.80-84, 2012.

PAE, C.U.; LIM, H.K.; HAN, C.; NEENA, A.; LEE, C.; PATKAR, A.A. Selegiline transdermal system: current awareness and promise. Prog. Neuropsychopharmacol. Biol. Psychiatry, v.31, p.1153-1163, 2007.
PAHARIA, A.; YADAV, A.K.; JAIN, S.K.; RAI, G.; PANCHOLI, S.S.; AGRAWAL, G.P. Eudragit coated pectin microspheres of 5-fluorouracil for colon targeting. AAPS PharmSciTech., v.8, p.E1-E7, 2007.

SAILAJA, A.K.; AMARESHWAR, P.; CHAKRAVARTY, P. Chitosan nanoparticles as a drug delivery system. Res. J. Pharm. Biol. Chem. Sci., v.1, p.474-484, 2010.

SENTHILKUMAR, R.; VAIDYANATHAN, S.; SIVARAMAN, B. Thermal analysis of heat pipe using Taguchi method. Int. J. Eng. Sci. Tech., v.2, p.564-69, 2010.

SHARMA, A.; KHATRI, K.; PATIL, U.K. Nasal route: a potential alternative for antiparkinsonism drug delivery. Int. J. Pharm. Tech. Res., v.2, p.2291-2306, 2010.

THAGELE, R.; MISHRA, A.; PATHAK, A.K. Formulation and characterization of clarithromycin based nanoparticulate drug delivery system. Int. J. Pharm. Life Sci., v.2, p.510$515,2011$.

VARSHOSAZ, J.; TAVAKOLI, N.; MINAYIAN, M.; RAHDARI, N. Applying the taguchi design for optimized formulation of sustained release gliclazide chitosan beads: an in vitro/in vivo study. AAPS PharmSciTech., v.10, p.15865, 2008 .

VASIR, J.K.; REDDY, M.K.; LABHASETWAR, V.K. Nanosystems in Drug Targeting: Opportunities and Challenges. Curr. Nanosci., v.1, p.47-64, 2005.

WANG, X.; CHI, N.; TANG, X. Preparation of estradiol chitosan nanoparticles for improving nasal absorption and brain targeting. Eur. J. Pharm. Biopharm., v.70, p.735-777, 2008.

WILSON, B.; SAMANTA, M.K.; SANTHI, K.; KUMAR, K.P.S.; PARAMAKRISHNAN, N.; SURESH, B. Targeted delivery of tacrine into the brain with polysorbate 80 -coated poly(n-butylcyanoacrylate) nanoparticles. Eur. J. Pharm. Biopharm., v.70, p.75-84, 2008.

ZHANG, Z.; LIAO, G.; NAGAI, T.; HOU, S. Mitoxantrone polybutylcyanoacrylate nanoparticles as an anti-neoplastic targeting drug delivery system. Int. J. Pharm., v.139, p.1-8, 1996.

Received for publication on $14^{\text {th }}$ June 2013 Accepted for publication on $23^{\text {rd }}$ March 2014 